
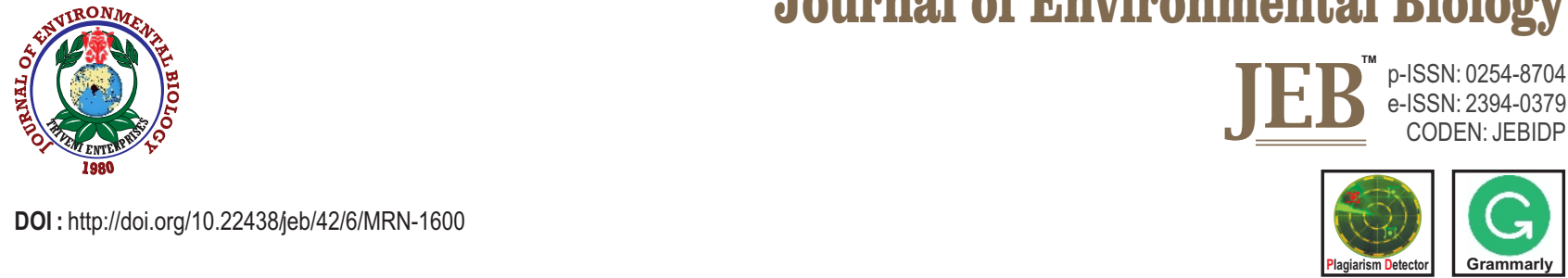

\title{
Unravelling genetic variability for moisture stress tolerance in Indian mustard and identification of high breeding value donor lines
}

\author{
S.K. Sandhu ${ }^{1 *}$, Sunayana ${ }^{2}$, L. Pal', I. Rialch ${ }^{1}$ and M. Singh ${ }^{2}$ \\ 'Department of Plant Breeding and Genetics, Punjab Agricultural University, Ludhiana-141 004, India \\ ${ }^{2}$ Dr JC Bakhshi Punjab Agricultural University, Regional Research Station, Abohar-152 116, India \\ *Corresponding Author Email : surindersandhu@pau.edu
}

\begin{abstract}
Aim: Identification of high breeding value donor lines harbouring tolerance to moisture stress from diversity stock of 443 genotypes of Brassica juncea.

Methodology: Germplasm stock of 443 Indian mustard (Brassica juncea L.) genotypes, comprising introgression lines, land races, old cultivars and advance breeding lines, were evaluated under two environments viz., irrigated and rainfed conditions to check the variability for yield and related traits. Statistical software META-Rver 6.0 (Multi Environment Trial Analysis using R) was used for computation of Best Linear Unbiased Predictions, Analysis of Variance (ANOVA), Genetic Correlations and Heritability. Drought susceptibility index and per cent seed yield reduction under rainfed conditions were used as indicators to determine moisture stress tolerance in genotypes.

Results: The variability for moisture stress tolerance has been unravelled in a diverse genetic stock of Brassica juncea under two environments: irrigated and rainfed. For high prediction accuracy, the ranking of genotypes was done based on Best Linear Unbiased Predictions for seed yield and its component traits. PBR-378, RGN-329, RB-73, RB-50 and PBR-422 and Giriraj were identified as moisture stress tolerant genotypes. One land race Sahib 36 and three introgression lines viz., MCP 12-211, PTJ-3-69 and MSC-3 have also been identified as potential genetic resources for moisture stress tolerance. Principal component analysis based on biplots depicted specific distribution of variables for each environment.

Interpretation: This study led to the identification of

Germplasm stock of 443 Indian mustard genotypes planted in alpha lattice design under irrigated and rainfed conditions at two locations $\sqrt{5}$

\begin{tabular}{|l|}
\hline Data was recorded at physiological maturity on all seed yield traits \\
\hline Statistical analysis includes BLUPS, ANOVA, genetic correlations, heritability and results were presented by dendrograms and PCA \\
\hline Drought Susceptibility Index (DSI) and per cent seed yield reduction under rainfed conditions (SYro) were used as indicators 6.0 (Multi-Environment Trait Analysis using R) was used for analysis of data and graphical \\
The lines in top 10 ranks for BLUP based seed yield viz., PBR-378, RGN-329, RB-73, RB-50 and PBR 422 were recommended to use \\
as parents in breeding programme for moisture stress tolerance
\end{tabular}
potential donors for moisture stress tolerance with high predictive accuracy. Low drought susceptibility index and high breeding value in a land race and three introgression lines derived from Erucastrum cardaminoides, $B$. tournefortii and $B$. carinata emphasized their utilization as potential genetic resources to breed for moisture stress tolerance in $B$. juncea.
\end{abstract}

Key words: Brassica juncea, Drought susceptibility index, Moisture stress, Seed yield

How to cite : Sandhu, S.K., Sunayana, L. Pal, I. Rialch and M. Singh: Unravelling genetic variability for moisture stress tolerance in Indian mustard and identification of high breeding value donor lines. J. Environ. Biol., 42, 1478-1487 (2021). 


\section{Introduction}

Oilseed crops, second only to food grains, form a significant part of Indian agricultural economy and is mainly grown for oil, condiments, vegetables or fodder (Ashraf and McNeilly, 2004). In India, Indian mustard (Brassica juncea) is a natural allotetraploid of diploid parents $B$. rapa and $B$. nigra; originated from the areas encompassing Mediterranean, IranoTuranian and Saharo-Sindian geographies (Nagaharu, 1935; Kaur et al., 2014). It accounts for more than $80 \%$ of the total rapeseed-mustard production and constitute essential part in the oilseed sector, nearly $28.6 \%$ of edible oil (GOI, 2017; Vinu et al., 2013). With the development of canola quality, $B$. juncea further expanded to drier regions in Australia and Canada (Parker, 1999) and developed as a complimentary oilseed crop to $B$. napus for cultivation in hot and low-rainfall areas where $B$. napus did not perform well and also infused with resistance to blackleg disease (Woods et al., 1991; Oram and Kirk, 1995).

Indian mustard crop is well adapted to low moisture cropping system due to low water requirement $(80-240 \mathrm{~mm})$ and $30.7 \%$ area is under rainfed cultivation in India. Though, India ranks $3^{\text {rd }}$ position after Canada and China in acreage (19.3\%) and after China and Canada in production $(11.1 \%)$ of rapeseedmustard, various abiotic stresses such as drought (approximately affecting $40 \%$ of the world's land area), salinity and cold spells has lea to low production of this crop in India (Trenberth et al., 2014; Luo et al., 2014). Spectacular increase in production (4.11 to 7.98 million tonnes) and productivity (560 to $1324 \mathrm{~kg} \mathrm{ha}^{-1}$ ) from 1980 to 2017 has been recorded due to development of high yielding varieties and improved production and protection technologies. In Punjab, about $30 \%$ (12.3 thousand ha) area of Indian mustard is confined to Western arid zone of state with average rainfall $<200$ $\mathrm{mm}$. In spite of good farm practices, the productivity of Indian mustard in Punjab state is 14.98 quintal per ha. Drought stress has great influence on source and sinks storage potential and leads to decline in number of seeds per pod, seed weight, overall productivity and seed oil content in Brassica (Chauhan et al., 2007; Sinaki et al., 2007). The reproductive phase of the plant is more susceptible to drought stress (Hall, 1992). There is an urgent need to develop varieties that can maintain optimum yield levels under abiotic stresses. However, due to multigenic and quantitative nature of stress tolerance in plants, efforts to improve crop performance under drought and salinity have been elusive. This challenge has given an impetus to plant scientists to improve drought and salt tolerance (Patel et al., 2018). There is great interest in breeding stress-tolerant varieties, since significant inter and intra-specific variation for drought and salinity tolerance exists within Brassica, which needs to be exploited through selection and breeding. For successful utilization of genetic variability, crop breeders emphatically searched for the traits of importance and subsequently to incorporate it genetically into cultivars (Zhang et al., 2007). There is a limited documentation for variation in moisture stress tolerance in $B$. juncea. Punjab Agricultural University, Ludhiana has enormous reservoir of $B$. juncea germplasm stock comprising introgression lines derived from wild relatives/species, land races, old cultivars and advance breeding lines.

Previous studies have indicated that drought susceptibility index values for seed yield and component traits served as a good indicator to phenotype drought tolerance (Chauhan et al., 2007; Ray et al., 2014). Seed yield is the final target, and selection for seed yield under dry conditions should be effective approach for improvement of drought resistance until more rapid and effective screening procedures are developed (Clarke et al., 1984; Vaishnava et al., 2006). In the present study, a fixed diversity stock of 443 lines of $B$. juncea was evaluated for genetic variability for moisture stress tolerance using Best Linear Unbiased Predictions, Drought Susceptibility Index, Principal Component Analysis and Genetic Variability parameters for the phenotyping of genotypes under irrigated and rainfed conditions. Further, the identified lines were recommended for use as donors in future breeding programme for tolerance to moisture stress.

\section{Materials and Methods}

A fixed diverse germplasm stock of 443 Indian mustard genotypes, comprising introgression lines, land races, old cultivars and advance breeding lines was used to unravel the variability for seed yield and its component traits under two different environments: Environment I (Irrigated conditions) and Environment II (rainfed conditions). The 443 genotypes were planted at two locations: Punjab Agricultural University (PAU), Ludhiana (represent Central zone of Punjab state; located at $30.9^{\circ} \mathrm{N}, 75.8^{\circ} \mathrm{E}$ ) and PAU Regional Research Station, Abohar, Fazilka (represent semi-arid plains with scattered sand dunes; located at $30.15^{\circ} \mathrm{N}, 74.19^{\circ} \mathrm{E}$ ) during 2018-19. All the genotypes were planted in an alpha lattice design in two replications with each genotype sown in a plot of two rows of $2 \mathrm{~m}$ at a row to row and plant to plant spacing of $30 \mathrm{~cm}$ and $10 \mathrm{~cm}$, respectively. At maturity, the crop was harvested manually. Data were recorded on five randomly selected plants of each genotype of each replication for traits, i.e., plant height, main shoot length, number of primary branches, number of secondary branches and number of siliquae on the main shoot. Seed yield was recorded on plot basis after drying seed of each genotype. Seed yield per plant was calculated by dividing seed yield per plot by number of plants harvested per plot. Statistical software META-R ver 6.0 (MultiEnvironment Trial Analysis using R) developed by CIMMYT was used for analysis of data and graphical representation of results of individual environments (irrigated and rainfed) and across environment (Alvarado et al., 2016). Drought susceptibility index was calculated by the formula of Fischer and Maurer (1978). Per cent seed yield reduction under rainfed conditions (SYr \%) was calculated by the formula: 


$$
S Y r \%=\frac{S Y_{\mathbb{R}}-S Y_{R F}}{S Y_{\mathbb{R}}} \times 100
$$

Statistical analysis included calculus of Best Linear Unbiased Predictors, Analysis of Variance (ANOVA), Genetic Correlations among environments, Genetic Correlations between variables and broad-sense heritability. The results have been presented by dendrograms and Principal Component Analysis biplots for comprehensible interpretation.

\section{Results and Discussion}

Genotypic values of variables viz., flowering traits: days to $50 \%$ flowering, days to $100 \%$ flowering and flowering duration; yield and its component traits viz., plant height, primary branch number, secondary branch number, main shoot length, number of siliquae per main shoot and siliqua length were determined in each environment- irrigated and rainfed. Table 1 shows variance components under irrigated and rainfed conditions. The data across locations viz., Ludhiana and Abohar were pooled for each environment. Heritability, an important predictor of the degree to which a population can respond to artificial or natural selection (Khan et al., 2003; Azam et al., 2013), was high for seed yield, plant height and flowering traits whereas less than 0.5 for primary branch number, secondary branch number, main shoot length, number of siliquae per main shoot and siliqua length under irrigated conditions. Under rainfed conditions, heritability was high for seed yield, plant height, days to $50 \%$ flowering and days to $100 \%$ flowering. The traits with high heritability were of main consideration for effective phenotypic selection. The diversity stock expressed high variability for all the traits, except no genotypic variance for flowering duration and siliquae length. Moisture stress might have led to forced flowering in all the genotypes and thereby hindering the genetic expression of test lines for these traits. As expected, under rainfed conditions, seed yield and its contributing traits exhibited reduction in mean values due to water stress but there was differential response of genotypes towards reduction under stress. Higher mean relative yield under irrigated conditions than rainfed conditions in Indian mustard genotypes has also been observed by Singh et al. (2018) and Sandhu et al. (2020).

The genetic correlations between two locations under each environment viz., irrigated and rainfed are presented in Table 2. All the variables were positively related between locations under irrigated condition, while under rainfed environment, siliqua length and flowering duration were not correlated in Ludhiana and Abohar conditions. Genetic correlations within a trait across environments $\left(r_{g}\right)$ are important for the analysis of phenotypic plasticity (Shukla et al., 2004). Best Linear Unbiased Predictions for all variables of 443 genotypes were calculated, considering genotypes as random effect, under each environment. No genotypic variance was observed for siliqua length and flowering duration under rainfed conditions. Estimation of genotypic values is the core of any breeding effort which requires a selection to be made among a larger set of candidate genotypes to develop new cultivars (Henderson, 1975). Piepho et al., (2008) demonstrated Best Linear Unbiased Predictions with good predictive accuracy for phenotypic selection in plant breeding and variety testing in comparison to other procedures. Hill and Rosenberger (1985) found Best Linear Unbiased Predictions to outperform Best Linear Unbiased Estimations.

Cluster analysis using ward method and principal component analysis based on environment distance matrix was

Table 1 : Best linear unbiased prediction based genetic components of test traits of $B$. juncea germplasm stock under irrigated and rainfed conditions.

\begin{tabular}{llllllllllll}
\hline Traits & $\begin{array}{l}\text { Environ- } \\
\text { ment }\end{array}$ & $\begin{array}{l}\text { Days to } \\
\mathbf{5 0 \%} \\
\text { flowering }\end{array}$ & $\begin{array}{l}\text { Days to } \\
\mathbf{1 0 0 \%} \\
\text { flowering }\end{array}$ & $\begin{array}{l}\text { Flowering } \\
\text { duration }\end{array}$ & $\begin{array}{l}\text { Plant } \\
\text { height } \\
\text { (cm) }\end{array}$ & $\begin{array}{l}\text { Primary } \\
\text { branch } \\
\text { number }\end{array}$ & $\begin{array}{l}\text { Secondary } \\
\text { branch } \\
\text { number }\end{array}$ & $\begin{array}{l}\text { Main } \\
\text { shoot } \\
\text { length } \\
\text { (cm) }\end{array}$ & $\begin{array}{l}\text { Number } \\
\text { of siliquae } \\
\text { per main } \\
\text { shoot }\end{array}$ & $\begin{array}{l}\text { Siliqua } \\
\text { length } \\
\text { (cm) }\end{array}$ & $\begin{array}{l}\text { Seed } \\
\text { yield } \\
\text { (gm) }\end{array}$ \\
\hline Heritability & Rainfed & 0.757 & 0.551 & 0 & 0.781 & 0.272 & 0.098 & 0.115 & 0.16 & 0 & 0.951 \\
& Irrigated & 0.836 & 0.658 & 0.594 & 0.768 & 0.162 & 0.33 & 0.269 & 0.219 & 0.039 & 0.948 \\
Genotype & Rainfed & 14.281 & 14.777 & 0 & 120.29 & 0.131 & 0.356 & 7.738 & 6.842 & 0 & 2.115 \\
variance & Irrigated & 21.02 & 20.954 & 13.941 & 130.24 & 0.085 & 1 & 17.901 & 10.885 & 0.008 & 2.052 \\
GenxLoc & Rainfed & 5.252 & 20.035 & 27.943 & 2.545 & 0.669 & 6.297 & 113.25 & 65.413 & 0.201 & 0 \\
Variance & Irrigated & 2.979 & 17.637 & 5.594 & 4.79 & 0.834 & 3.686 & 90.148 & 70.632 & 0.341 & 0 \\
Residual & Rainfed & 7.84 & 8.008 & 24.628 & 129.485 & 0.065 & 0.52 & 11.62 & 12.867 & 0.043 & 0.439 \\
Variance & Irrigated & 10.554 & 8.303 & 26.876 & 147.977 & 0.099 & 0.756 & 14.577 & 14.137 & 0.082 & 0.452 \\
Grand Mean & Rainfed & 59.857 & 69.284 & 126.01 & 186.044 & 4.446 & 10.38 & 59.166 & 50.199 & 4.16 & 7.803 \\
& Irrigated & 62.458 & 73.572 & 129.477 & 203.414 & 5.4 & 13.066 & 64.301 & 54.761 & 4.292 & 8.65 \\
LSD & Rainfed & 3.668 & 5.063 & 0 & 10.102 & 0.607 & 1.114 & 5.143 & 4.712 & 0 & 0.64 \\
& Irrigated & 3.66 & 5.266 & 4.679 & 10.833 & 0.525 & 1.609 & 7.112 & 5.732 & 0.171 & 0.648 \\
CV (\%) & Rainfed & 4.678 & 4.084 & 3.938 & 6.116 & 5.748 & 6.946 & 5.761 & 7.146 & 5.013 & 8.492 \\
& Irrigated & 5.202 & 3.917 & 4.004 & 5.98 & 5.813 & 6.654 & 5.938 & 6.866 & 6.654 & 7.772 \\
\hline
\end{tabular}


Table 2 : Genetic correlations $\left(r_{g}\right)$ of traits of $B$. juncea germplasm stock between locations of each environment.

\begin{tabular}{|c|c|c|c|c|}
\hline \multirow[t]{2}{*}{ Traits } & \multicolumn{2}{|c|}{ Irrigated-Ludhiana and Abohar } & \multicolumn{2}{|c|}{ Rainfed-Ludhiana and Abohar } \\
\hline & $r_{g}$-value & Probability & $r_{g}$-value & Probability \\
\hline Days to $50 \%$ flowering & 0.876 & 0.319 & 0.733 & 0.476 \\
\hline Days to $100 \%$ flowering & 0.551 & 0.627 & 0.444 & 0.707 \\
\hline Flowering duration & 0.753 & 0.456 & -0.142 & 0.909 \\
\hline Plantheight (cm) & 0.965 & 0.168 & 0.999 & 0.009 \\
\hline Primary branch number & 0.096 & 0.938 & 0.167 & 0.893 \\
\hline Secondary branch number & 0.219 & 0.858 & 0.056 & 0.964 \\
\hline Main shoot length $(\mathrm{cm})$ & 0.183 & 0.882 & 0.064 & 0.958 \\
\hline Number of siliquae on main shoot & 0.162 & 0.896 & 0.105 & 0.933 \\
\hline Siliqua length $(\mathrm{cm})$ & 0.022 & 0.985 & -0.061 & 0.961 \\
\hline Seed yield (gm) & 0.990 & 0.009 & 0.999 & 0.009 \\
\hline
\end{tabular}

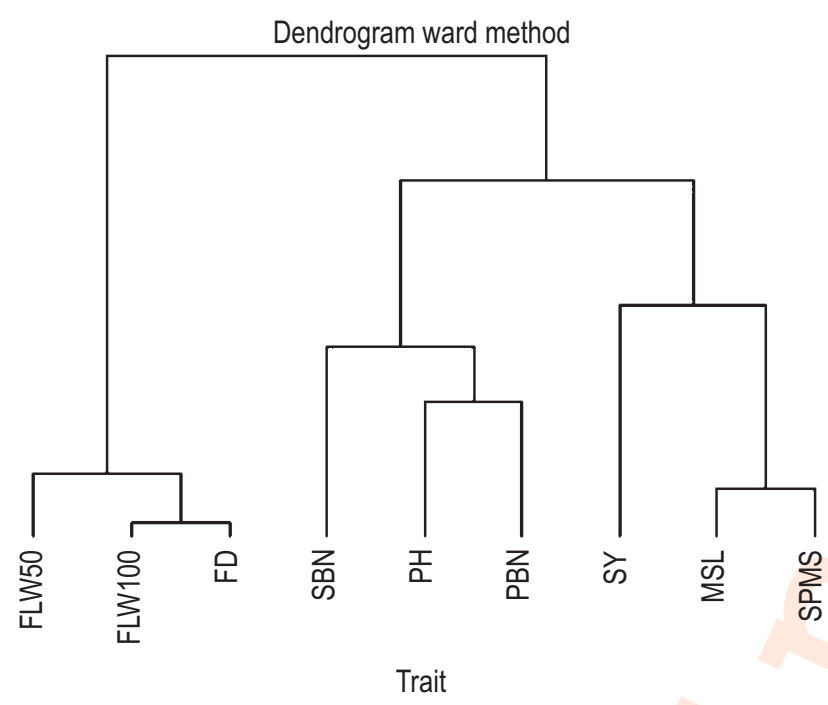

Fig. 1(a): Grouping profile of traits of $B$. juncea genotypes under irrigated conditions. FLW50: Days to 50\% flowering; FLW100: Days to $100 \%$ flowering; FD: Flowering duration; SBN: Secondary branch number; $\mathrm{PH}$ : Plant height (cm); PBN: Primary branch number; SY: Seed yield (g); MSL: Main shoot length (cm); SPMS: Number of siliquae on main shoot.

used to assemble dendrogram and biplot, respectively. The minimum heritability threshold of 0.05 was set up for calculations. As depicted in Fig.1a under irrigated conditions, dendrogram grouped variables into two main groups- one grouped flowering traits and other grouped plant and seed yield traits which were further sub grouped as secondary branch number, primary branch number and plant height (Sub group 1) and seed yield, main shoot length and number of siliquae per main shoot (subgroup 2). Fig. 2a shows biplot to graphically visualise the genotypic correlations of variables under irrigated condition. PC1, which explained 42.1 per cent of total variation, was positively related to plant height, primary branch number and secondary branch number. All flowering traits were significantly correlated to each other but not found interacting with other test traits. Seed yield and plant height, as depicted by short arrows, did not show

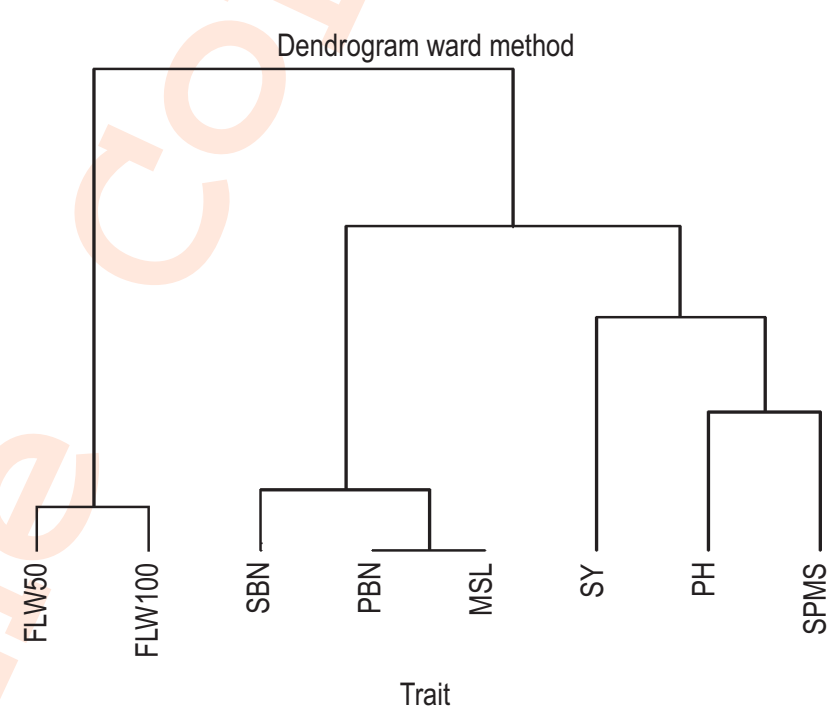

Fig. 1(b) : Grouping profile of traits of $B$. juncea genotypes under rainfed conditions. FLW50: Days to 50\% flowering, FLW100: Days to $100 \%$ flowering; SBN: Secondary branch number; PBN: Primary branch number; MSL: Main shoot length (cm); SY: Seed yield (g); PH: Plant height $(\mathrm{cm})$; SPMS: Number of siliquae on main shoot.

high variability. PC2 explained 28.6 per cent of variation with number of siliquae per main shoot as a major contributor. Main shoot length appeared as one of the main determinants of seed yield followed by siliquae per main shoot, as it was highly correlated. Similarly, genetic correlations among variables under rainfed condition were explained through Fig.1b. Similar to irrigated conditions, flowering traits grouped separately from rest of variables - secondary branch number, primary branch number and main shoot length as subgroup 1 and seed yield, plant height and number of siliquae per main shoot as sub group 2. Number of siliquae per main shoot as one of the major seed yield determining traits in $B$. juncea was also documented by Sandhu et al. (2019). The results showed less genetic variability for siliqua length in our germplasm stock. Meena et al. (2017) also reported less genetic variability for siliqua length in Indian mustard 


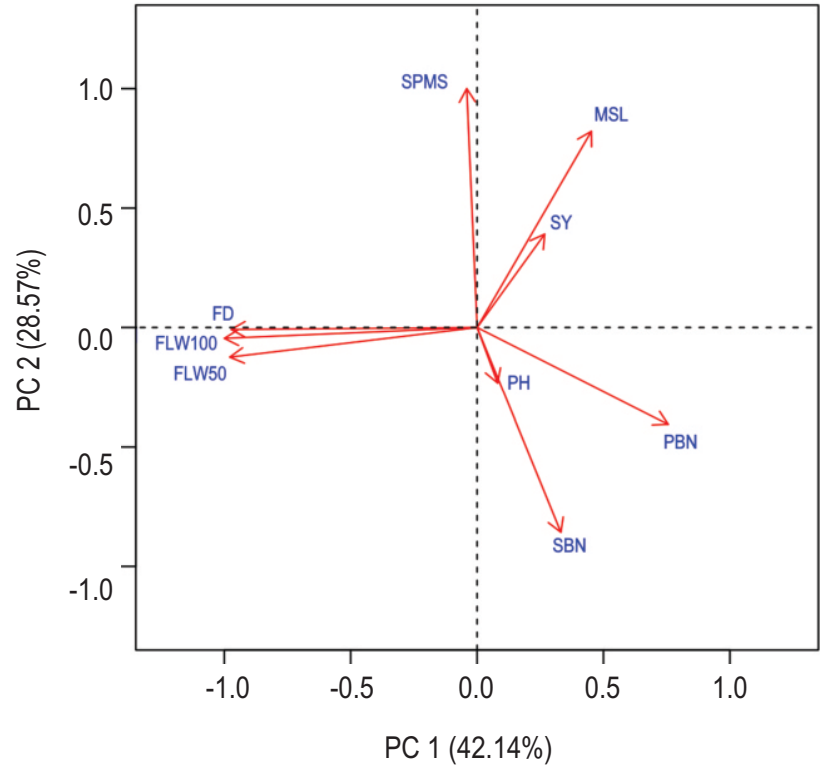

Fig. 2(a) : Biplot graph on genetic correlation among traits of $B$. juncea under irrigated conditions. FLW50: Days to 50\% flowering; FLW100: Days to $100 \%$ flowering; FD: Flowering duration; SBN: Secondary branch number; PH: Plant height (cm); PBN: Primary branch number; SY: Seed yield (g); MSL: Main shoot length $(\mathrm{cm})$; SPMS: Number of siliquae on main shoot.

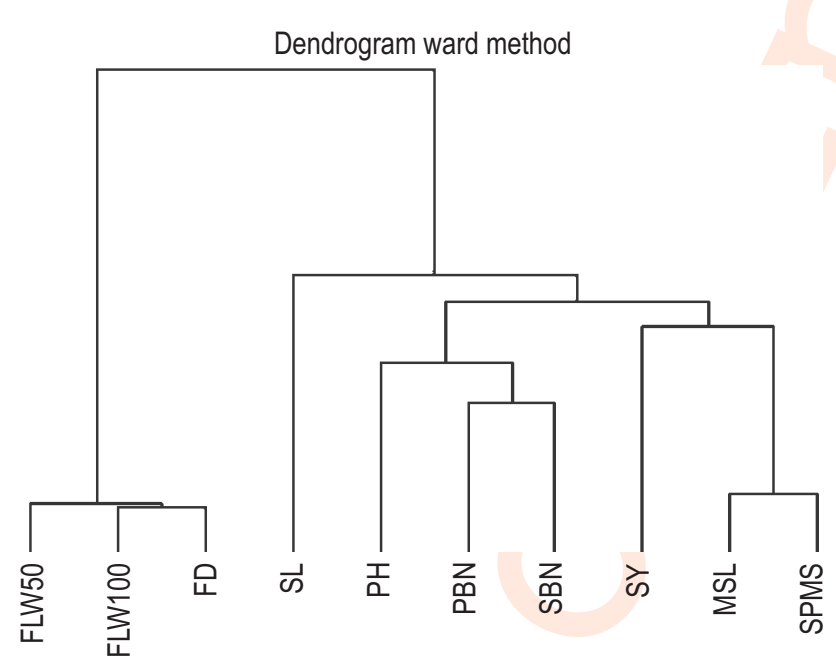

Trait

Fig. 3 : Grouping profile of variables of Brassica juncea genotypes combined across environments. FLW50: Days to $50 \%$ flowering, FLW100: Days to $100 \%$ flowering, FD: Flowering duration, SL: Siliqua length $(\mathrm{cm}), \mathrm{PH}$ : Plant height $(\mathrm{cm}), \mathrm{PBN}$ : Primary branch number, SBN: Secondary branch number, SY: Seed yield (g), MSL: Main shoot length $(\mathrm{cm})$, SPMS: Number of siliquae on main shoot.

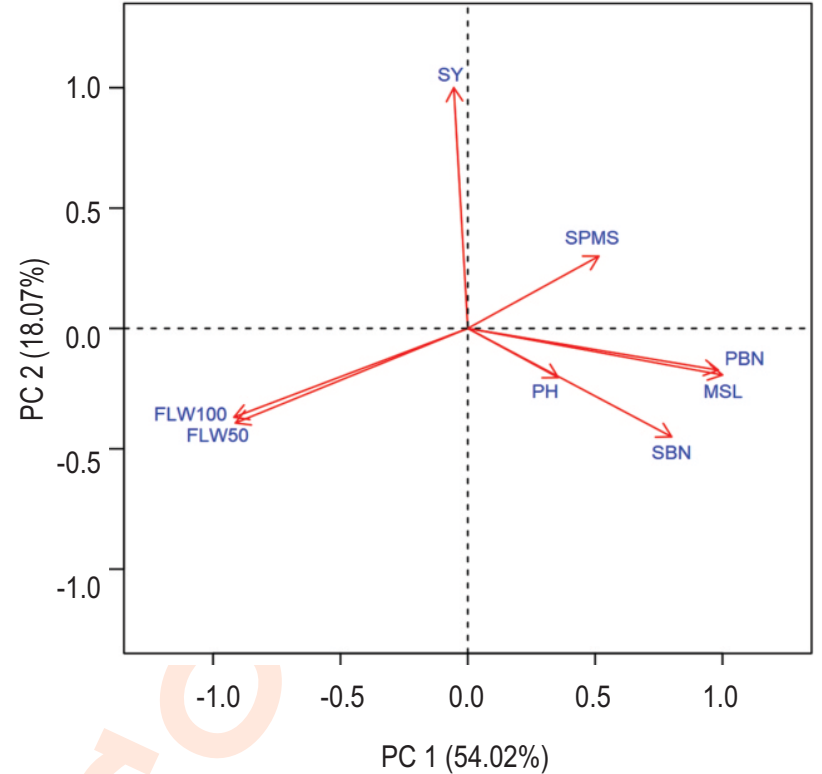

Fig. 2(b) : Biplot graph on genetic correlation among traits of $B$. juncea under rainfed conditions. FLW50: Days to 50\% flowering; FLW100: Days to $100 \%$ flowering; SBN: Secondary branch number; PBN: Primary branch number; MSL: Main shoot length (cm); SY: Seed yield (g); PH: Plant height (cm); SPMS: Number of siliquae on main shoot.

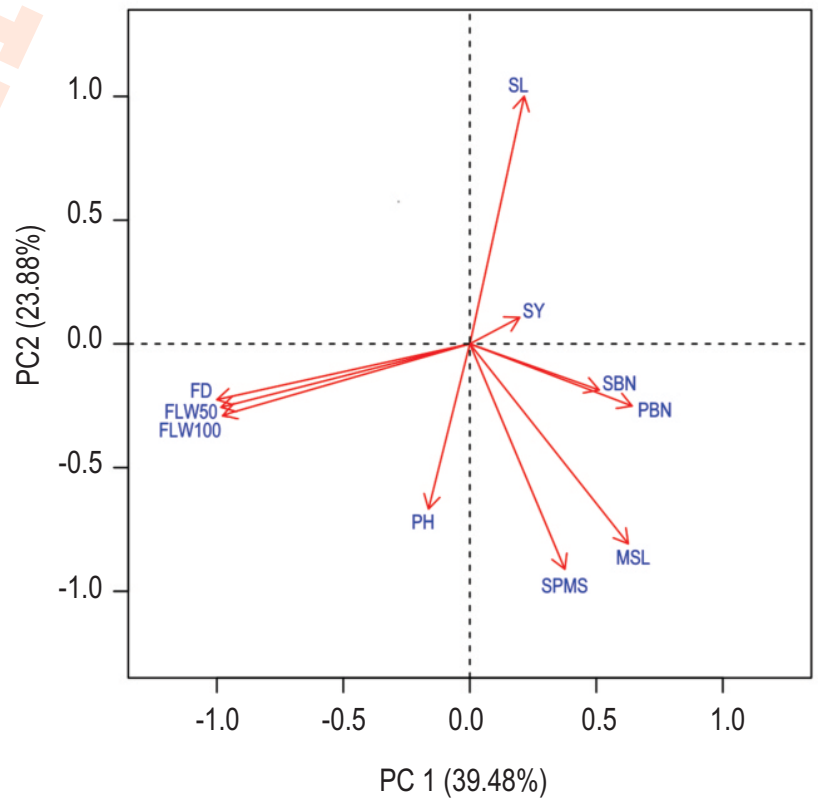

Fig. 4 : Biplot graph on genetic correlation among traits of $B$. juncea across environments.FLW50: Days to 50\% flowering; FLW100: Days to 100\% flowering; FD: Flowering duration, SL: Siliqua length $(\mathrm{cm}), \mathrm{PH}$ : Plant height $(\mathrm{cm})$; PBN: Primary branch number; SBN: Secondary branch number; SY: Seed yield (g); MSL: Main shoot length (cm); SPMS: Number of siliquae on main shoot. 
genotypes. Principal Component Analysis based biplot (Fig. 2b) recorded PC1 having positive genetic correlation with plant height, primary branch number, secondary branch number and main shoot length whereas negatively related to flowering traits (days to $50 \%$ flowering and days to $100 \%$ flowering). PC2, which explained about $18 \%$ of variation, was mainly determined by seed yield. Unlike under irrigated condition, the genotypes expressed high variability for seed yield under rainfed condition, thereby indicating that genotypes expressed highly differential productivity response under moisture stress. This also provided ample scope for selecting moisture stress tolerant genotypes. Primary branch number and secondary branch number were closely related, which implies that if one trait is selected then there are chances for the improvement in another trait.

The differences in the extent of variations in each test variable (as depicted by length of vector) and the nature of genetic correlations among variables (as depicted by angle between variables in bilpots) in each environment emphasized the need to evaluate germplasm in target environment for effective selection of parents. As implied by Principal Component Analysis, traits determining variability under rainfed conditions differed from those under irrigated conditions and this information is necessary for effective phenotypic selection of genotypes.

Grouping pattern of variables in pooled data across environments is presented in Fig. 3. Siliqua length was recorded, unexpectedly, with high genotypic variability, as the main component of $\mathrm{PC} 2$, explaining $23.8 \%$ variation (Fig. 4). The selection based on seed yield contributing traits, instead of seed yield alone, may serve better, especially in initial breeding generations (Sandhu et al., 2020). Grouping based on phenotypic traits associated with drought-tolerant or salt-tolerant crops serve as important breeding tools for identifying stress-tolerant genotypes and introducing such tolerant traits into cultivated genotypes (Zhang etal., 2014).

Best Linear Unbiased Predictions based genotypic values of seed yield for each genotype was determined for both the environments (irrigated and rainfed) as well as pooled across locations. Drought susceptibility index and SYr\% were also estimated from the observed traits. Drought susceptibility index of

Table 3 : Drought susceptibility index and percent seed yield reduction (SY\%) of top 23 (out of 443 ) moisture stress tolerant genotypes of Brassica juncea

\begin{tabular}{|c|c|c|c|c|c|}
\hline Genotypes & Description & $\begin{array}{l}\text { Best linear unbiased } \\
\text { prediction based } \\
\text { seed yield under } \\
\text { irrigated condition }\end{array}$ & $\begin{array}{l}\text { Best linear unbiased } \\
\text { prediction based } \\
\text { seed yield under } \\
\text { rainfed condition }\end{array}$ & $\begin{array}{l}\text { Seed yield based } \\
\text { drought } \\
\text { susceptibility index }\end{array}$ & $\mathrm{SY}_{\mathrm{r}} \%$ \\
\hline DRMR-08-293 & Advance breeding line & 8.65 & 10.23 & -1.84 & -18.19 \\
\hline PBR 97 & Variety for cultivation under moisture stress & 9.71 & 10.35 & -0.66 & -6.50 \\
\hline MCP-12-211 & $\begin{array}{l}\text { Derived B. juncea line from B. juncea } x \\
\text { Erucastrum cardaminoides }\end{array}$ & 9.71 & 10.29 & -0.60 & -5.92 \\
\hline BPR-55 & Heat tolerant breeding line & 9.08 & 9.54 & -0.52 & -5.10 \\
\hline RH-0406 & Variety for cultivation under moisture stress & 8.79 & 9.23 & -0.51 & -5.02 \\
\hline Sahib-36 & Land race & 8.47 & 8.84 & -0.44 & -4.38 \\
\hline PBR-378 & Variety for cultivation under moisture stress & 10.75 & 11.18 & -0.41 & -4.05 \\
\hline $\mathrm{RH}-0749$ & Variety for cultivation under moisture stress & 9.92 & 10.31 & -0.40 & -3.93 \\
\hline RK-06-2 & Advanced breeding line & 8.32 & 8.64 & -0.39 & -3.83 \\
\hline JMG-244 & Germplasm line & 5.24 & 5.42 & -0.35 & -3.45 \\
\hline MSC-3 & $\begin{array}{l}\text { B. juncea line from B.juncea } x \text { B. carinata } \\
\text { hybridization }\end{array}$ & 9.22 & 9.53 & -0.34 & -3.33 \\
\hline PCR-3 & Germplasm line & 8.50 & 8.73 & -0.28 & -2.77 \\
\hline RGN-282 & Advanced breeding line & 10.58 & 10.84 & -0.24 & -2.40 \\
\hline PTJ-3-69 & $\begin{array}{l}\text { B. juncea introgression line from } \\
\text { B. tournefortii x } B \text {. juncea }\end{array}$ & 7.90 & 8.08 & -0.23 & -2.27 \\
\hline PRG-2001-62 & Germplasm line & 8.14 & 8.32 & -0.23 & -2.27 \\
\hline PBR-422 & Advanced breeding line & 10.73 & 10.94 & -0.20 & -1.97 \\
\hline RRN-671 & Advanced breeding line & 9.20 & 9.35 & -0.17 & -1.66 \\
\hline RB-50 & Variety for cultivation under moisture stress & 10.77 & 10.94 & -0.16 & -1.55 \\
\hline RGN-197 & Advanced breeding line & 9.42 & 9.57 & -0.15 & -1.52 \\
\hline RB-73 & Advanced breeding line & 10.78 & 10.94 & -0.15 & -1.50 \\
\hline RGN-329 & Advanced breeding line & 10.85 & 10.96 & -0.10 & -0.97 \\
\hline RRN-598 & Advanced breeding line & 8.92 & 8.94 & -0.03 & -0.31 \\
\hline Giriraj & $\begin{array}{l}\text { High yielding variety suitable for terminal } \\
\text { heat stress }\end{array}$ & 10.21 & 10.21 & 0.00 & -0.01 \\
\hline
\end{tabular}


Table 4: Ranking of elite moisture stress tolerant $B$. juncea lines along with genotypic values for seed yield and its component traits

\begin{tabular}{llllllll}
\hline Genotypes & Ranking $^{\text {s }}$ & $\begin{array}{l}\text { Seed yield/ } \\
\text { plant }(\mathbf{g})\end{array}$ & $\begin{array}{l}\text { Plantheight } \\
(\mathbf{c m})\end{array}$ & $\begin{array}{l}\text { Number of } \\
\text { primary } \\
\text { branches }\end{array}$ & $\begin{array}{l}\text { Number of } \\
\text { secondary } \\
\text { branches }\end{array}$ & $\begin{array}{l}\text { Main shoot } \\
\text { length }(\mathbf{c m})\end{array}$ & $\begin{array}{l}\text { Number of } \\
\text { siliquae on } \\
\text { main shoot }\end{array}$ \\
\hline PBR-378 & 3 & 11.03 & 182.59 & 4.39 & 11.73 & 61.66 & 49.98 \\
RGN-329 & 5 & 10.97 & 195.18 & 4.64 & 11.60 & 65.37 & 54.85 \\
RB-73 & 6 & 10.93 & 199.52 & 4.57 & 11.81 & 58.98 & 49.31 \\
RB-50 & 7 & 10.92 & 178.06 & 5.09 & 11.16 & 60.58 & 53.08 \\
PBR-422 & 9 & 10.90 & 183.56 & 4.59 & 10.74 & 61.02 & 48.17 \\
RGN-282 & 12 & 10.77 & 186.78 & 4.50 & 10.94 & 54.08 & 49.47 \\
Giriraj & 40 & 10.26 & 186.32 & 4.77 & 11.69 & 62.37 & 52.73 \\
RH0749 & 49 & 10.16 & 190.84 & 4.73 & 11.55 & 60.93 & 53.30 \\
PBR97 & 56 & 10.07 & 192.02 & 4.41 & 10.90 & 63.05 & 53.98 \\
MCP-12-211 & 57 & 10.04 & 194.30 & 5.05 & 12.18 & 61.10 & 52.21 \\
RGN-197 & 87 & 9.53 & 187.25 & 4.33 & 11.84 & 63.90 & 53.27 \\
DRMR-08-293 & 94 & 9.47 & 196.88 & 5.24 & 11.98 & 64.67 & 54.32 \\
MSC-3 & 101 & 9.40 & 183.59 & 4.42 & 10.80 & 62.24 & 52.87 \\
BPR-55 & 109 & 9.33 & 200.12 & 4.70 & 11.81 & 62.30 & 53.07 \\
RRN-671 & 112 & 9.30 & 187.21 & 5.04 & 12.51 & 61.16 & 49.13 \\
RH-0406 & 133 & 9.02 & 196.28 & 4.81 & 11.35 & 61.53 & 52.04 \\
RRN-598 & 139 & 8.95 & 191.72 & 5.12 & 11.78 & 63.11 & 53.56 \\
TNM-17 & 155 & 8.79 & 200.91 & 4.70 & 11.35 & 58.19 & 49.82 \\
Sahib-36 & 168 & 8.66 & 185.70 & 5.05 & 12.54 & 57.15 & 49.39 \\
PCR-3 & 174 & 8.62 & 208.74 & 4.55 & 11.73 & 57.65 & 51.44 \\
RK-06-2 & 187 & 8.48 & 190.43 & 5.02 & 12.57 & 62.48 & 52.92 \\
PRG-2001-62 & 226 & 8.23 & 191.08 & 4.75 & 11.09 & 60.84 & 52.92 \\
JMG-244 & 436 & 5.26 & 191.51 & 5.24 & 11.02 & 54.71 & 50.56 \\
LSD & & 0.47 & 8.85 & 0.62 & 1.42 & 6.61 & 5.41 \\
CV\% & & 8.33 & 6.05 & 5.81 & 6.81 & 5.86 & 7.00 \\
\hline Rankin & & & & & &
\end{tabular}

${ }^{\text {s}}$ Ranking based on estimated breeding value of seed yield of each donor

genotypes, estimated based on yield reduction under stress relative to yield under non-stress conditions, has been efficiently used as an indicator to determine drought tolerance in Brassicas (Rosielle and Hamblin, 1981; Fernandez, 1992). Shiranirad and Abbasian (2011) designated stress tolerance index as the most appropriate index for drought stress tolerance evaluation due to highest correlation with seed yield in both water and non-water stress conditions. Drought susceptibility index was calculated for each genotype as a decisive factor of its drought tolerance. In stock of 443 genotypes, drought susceptibility index value ranged from -1.84 (most tolerant) to 3.24 (most susceptible to moisture stress). Top 23 genotypes (Table 3 ) having negative drought susceptibility index, thereby indicating slight increase in seed yield under moisture stress, were identified as moisture stress tolerant genotypes. Clarke et al. (1984) demonstrated that under drought conditions, selection for seed yield should only be additional prolific possibility for enhancing drought resistance until more quick and efficient selection measures are developed. Ram et al. (2021) also observed that selection for tolerant genotype based on yield attributes can considerably improve yield potential under adverse environmental situation. As drought susceptibility index is a ratio, a genotype might have lower value of drought susceptibility index, while its mean seed yield under drought condition is considerably lower as compared to best performing genotype(s). In order to choose the best genotype under drought condition, Winter et al. (1988) used high mean seed yield along with lower drought susceptibility index value as selection criteria. Drought susceptibility index values and seed yield under drought conditions, as selection criteria in Indian mustard, have also been reported by Singh and Choudhary (2003).

The negative seed yield reduction also indicated no negative effect of moisture stress on these selected genotypes. This set of tolerant lines comprised commercial varieties released for rainfed conditions (PBR-97, PBR-378, RB-50, RH-406 and $\mathrm{RH}-749)$, variety released for tolerance to terminal heat stress (Giriraj), a land race, PAU developed advance breeding lines and three introgression lines viz., MCP-12-211, MSC-3 and PTJ-3-69.

MCP-12-211 is derived from $B$. juncea x Erucastrum cardaminoides. The history of evolution of Erucastrum cardaminoides $\left(2 n=18, E^{\text {cd }} E^{\text {cd }}\right)$ makes it a likely source of gene(s) against many abiotic and biotic stresses (Warwick et al., 2000) 
and is capable of gene exchange with the Brassicas (Chandra et al., 2004). B. juncea line MSC-3 was derived from $B$. juncea $\times$ B. carinata hybridization. PTJ-3-69 was derived from Brassica tournefortii x B. juncea. B. tournefortii Gouan. $(2 \mathrm{n}=20)$, Asian mustard, has been reported to grow sporadically in few pockets of arid and semi-arid areas and has been well documented as potential donor for drought tolerance (Salisbury, 1989; Prakash and Bhat, 2007). Wild relatives have been identified as genetic resources to develop new cultivars with biotic and abiotic stress resistance (Prakash et al., 2009; Kaneko and Bang, 2014). Rashidi et al. (2017) reported Brassica carinata A. Braun, 2n=34 (Ethiopian or Abyssinian mustard), as a drought tolerant species of Brassicas. Earlier, Jiang et al. (2007) recorded this species as a potential crop for dry land cultivation under rainfed conditions as it possess excellent drought and heat tolerant attributes. Interspecific hybridization as a potential method for transferring valuable traits between species of commercial interest in Brassica, has been well documented (Navabi et al., 2010; Malek et al., 2012; Rana et al., 2017). After validation in larger yield trials, identified donor lines can be utilized in commercial breeding program targeted at moisture stress tolerance. The donors identified on the basis of drought susceptibility index alone may not be the lines with high commercial values and hence, for less utility to breeder for use as parents in commercial breeding viz., JMG-244. Hence, to identify donors with high seed yield, the stock of 443 genotypes was ranked based on breeding values for seed yield, calculated across the environments. The lines with overall high breeding values for agronomic traits and lesser seed yield reduction (low drought susceptibility index) across environments may serve as better parents (Table 4). The lines with high overall productivity and high additive effects should be used in crossing programme so that the lines with high additive effects can be crossed with each other (Burgueno et al., 2007). The lines in top 10 ranks for Best Linear Unbiased Predictions based seed yield viz., PBR-378, RGN-329, RB-73, RB-50 and PBR-422 were recommended to be used as parents in breeding programme for tolerance moisture stress. Theses genotypes viz., MCP12-211, PBR -378, RB-5 and RRN-598 show cross tolerance, as these lines have tolerance to terminal heat stress as well as moisture stress. Thus, cross-tolerance, a response to one stress also helps to protect the plant from another coincident or subsequent environmental stress is a broadly described phenomenon in plants (Rivero et al., 2014).

The information generated in the present study revealed that genotypes, with the lowest drought susceptibility index, would serve as useful donors in the future breeding programme for improving the moisture stress tolerance of existing Indian mustard cultivars under field conditions. Utilization of land races and wild species as potential genetic resources to breed for abiotic stress tolerance has also been emphasized.

\section{Acknowledgments}

The Indian mustard germplasm, used in this study, was collected/developed and maintained by ICAR National Professor
Dr. S.S. Banga. The authors duly acknowledge the receipt of germplasm. Authors acknowledge the support provided by Dr. P.K. Arora, Director, Regional Research Station, Abohar for the conducting the experiment.

\section{Add-on Information}

Author's contribution : S.K. Sandhu: Planning, execution, manuscript writing and conduct of experiment at PAU, Ludhiana; Sunayana: For conduct of trials at Abohar and compilation of data; L. Pal: For conduct of analysis of data and inferences; I. Rialch: For assisting in conduct of trials at Ludhiana; M. Singh: For assisting in conduct of trials at Abohar.

Research content: The research content of manuscript is original and has not been published elsewhere.

Ethical approval: Not applicable

Conflict of interest: The authors declare that there is no conflict of interest.

Data from other sources: Not applicable

Consent to publish: All authors agree to publish the paper in Journal of Environmental Biology.

\section{References}

Alvarado, G., M. López, M. Vargas, A. Pacheco, F. Rodríguez, J. Burgueño and J. Crossa: META-R (multi environment trial analysis with $\mathrm{R}$ for windows) version 6.0. CIMMYT http://hdl.handle.net/ 11529/10201 (2016).

Ashraf, M. and T. McNeilly: Salinity tolerance in Brassica oilseeds. Crit. Rev. Plant Sci., 23, 157-174 (2004).

Azam, S.M., Farhatullah, A. Nasim, S. Shah and S. Iqbal. Correlation studies for some agronomic and quality traits in Brassica napus $\mathrm{L}$. Sarhad J. Agric., 29, 547-550 (2013).

Burgueno, J., J. Crossa, P.L. Cornelius, R. Trethowan, G. McLaren and A. Krishnamachari: Modeling additive $\times$ environment and additive $x$ additive $x$ environment using genetic covariance of relatives of wheat genotypes. Crop Sci., 47, 311-320 (2007).

Chandra, A., M.L. Gupta, I. Ahuja, G. Kaur and S.S. Banga: Intergeneric hybridization between Erucastrum cardaminoides and two diploid Brassica species. Theor. Appl. Genet., 108, 1620-1626 (2004).

Chauhan, J.S., M.K. Tyagi, A. Kumar, N.I. Nashaat and M. Singh: Drought effects on yield and its components in Indian mustard (Brassicajuncea L.). Plant Breed., 126, 399-402(2007).

Clarke, J., T.F. Smith, T.N. Mc Caaig and D.M. Green: Growth analysis of spring wheat cultivars of varying drought resistance. Crop Sci., 56, 603-626(1984).

Fernandez, G.C.J.: Effective selection criteria for assessing plant stress tolerance. In: Adaptation of Food Crops to Temperature and Water Stress (Ed.: C.G. Kuo): Proceedings of an International Symposium, Taiwan. Asian Veg. Res. Dev., 23, 257-270 (1992).

Fischer, R.A. and R. Maurer: Drought resistance in spring wheat cultivars for grain yield responses in spring wheat. Aust. J. Ag. Sci., 29, 892912(1978). 
GOI (Government of India): Agricultural Statistics Division, Department of Agriculture Cooperation \&amp; Farmers welfare, GOI, New Delhi. http:/agricoop.nic.in/statistics/advance-estimate-apyenglish, (2017).

Hall, A.E.: Breeding for heat tolerance. Pl. Breed. Rev., 10, 129-168 (1992).

Henderson, C.R.: Best linear unbiased estimation and prediction under a selection model. Biometrics, 12, 423-447(1975).

Hill, R.R. and J.L. Rosenberger: Methods for combining data from germplasm evaluation trials. Crop Sci., 25, 467-470 (1985).

Jat, R.S., V.V. Singh, P. Sharma and P.K. Rai: Oilseed Brassica in India: Demand, Supply, Policy Perspective and Future Potential. ICARDirectorate of Rapeseed Mustard Research (2019).

Jiang, Y., E. Tian, R. Li, L. Chen and J. Meng: Genetic diversity of Brassica carinata with emphasis on the interspecific crossability with B. rapa. Plant Breed., 126, 487-491(2007).

Kaneko, Y. and S.W. Bang: Interspecific and intergeneric hybridization and chromosomal engineering of Brassicaceae crops. Breed. Sci., 64, 14-22 (2014)

Kaur, H., S. Gupta, N. Kumar, J. Akhatar and S.S. Banga: Progression of molecular and phenotypic diversification in resynthesized Brassica juncea $(\mathrm{L})$ gene pool with determinate inflorescence. Euph., 199, 325-338 (2014).

Khan, A.S., I. Salim and Z. Ali: Heritability of various morphological traits in wheat. Int. J. Agric. Bio., 10, 138-140 (2003).

Luo, Y., X. Zhao, H. Qu, X. Zuo, S. Wang, W. Huang, Y. Luo and M. Chen: Photosynthetic performance and growth traits in Indian mustard exposed to drought and rewatering under different soil nutrient regimes. Acta Physiol. Plant., 36, 381-388 (2014).

Malek, M.A., M.R. Ismail, M.I. Rafi and M. Rahman: Synthetic Brassica napus L.: Development and studies on morphological characters, yield attributes and yield. The Sci. World J., 3, 1-6 (2012).

Meena, H.S., V.V. Kumar, P.D. Singh, B. Meena and S. Kulshrestha: Genetic variability and inter-relation of seed yield with contributing traits in Indian mustard (Brassica juncea). J. Oil. Brass., 8, 131137(2017).

Minnich, R.A. and A.C. Sanders: Brassica tournefortii. In: Invasive plants of California's Wildlands (Eds.: C.C. Bossard, J.M. Randall and M.C. Hoshovsky). University of California Press, Berkeley (2000).

Nagaharu, U.: Genome analysis in Brassica with special reference to the experimental formation of $B$. napus and peculiar mode of fertilization. J. Jap. Bot., 7, 389-452 (1935).

Navabi, Z.K., K.E. Stead, J.C. Pires, Z. Xiong, A.G. Sharpe, A.P. Parkin, M.H. Rahman and A.G. Good: Analysis of B-Genome chromosome introgression in interspecific hybrids of Brassica napus X B. carinata. Genet., 187, 659-73 (2010).

Oram, R.N. and J.T.O. Kirk: Developing double low Indian mustard for the Australian Wheatbelt. 10th Australian Research Assembly on Brassicas (Ed. T. D. Potter)., pp. 90-93 (1995).

Parker, P.: The mustard industry in Australia-Opportunities for a new oilseed. In.: Oilseed Crop Updates (Ed.: G. Shea). Agriculture WesternAustralia, pp.12-13 (1999).

Patel, R., R.C. Yadav, S. Jangra, G.D. Boken, B. Singh and N.R. Yadav: Genetic diversity analysis for salinity tolerance in Indian mustard [Brassica juncea (L.)] using SSR markers. Int. J. Curr. Microbiol. App. Sci., 7, 1776-1785(2018).

Piepho, H.P., J. Möhring, J.E. Melchinger and A. Büchs: Best linear Unbiased Predictions for phenotypic selection in plant breeding and variety testing. Euph., 161, 209-228 (2008).
Prakash, S. and S.R. Bhat: Contribution of wild crucifers in Brassica improvement: past accomplishment and future perspectives. Proceedings GCIRC 12th International Rapeseed Congress, 1, pp. 213-215 (2007).

Prakash, S., S.R. Bhat, C.F. Quiros, P.B. Kirti and V.L. Chopra: Brassicas and close allies: Cytogenetics and evolution. Plant Breed. Rev., 31, 56-89 (2009).

Rakow, G. and A. Getinet: Brassica carinata an oilseed crop for Canada. Acta Hort., 459, 419-428 (1997).

Ram B., Priyamedha, M.S. Sujith Kumar, H.K. Sharma, R. Rani, K.H. Singh, V.V. Singh, V. Kumar and P.K. Rai: Development and evaluation of early maturing thermo-tolerant Indian mustard (Brassica juncea L. Czern \& Coss) genotypes for cultivation in semi-arid region of India. Electron. J. Plant Breed., 12, 200-206 (2021).

Rana, K., C. Atri and M. Gupta: Mapping resistance responses to Sclerotinia infestation in introgression lines of Brassica juncea carrying genomic segments from wild Brassicaceae $B$. fruticulosa. Sci. Rep., 7, 5904 (2017).

Rashidi, F., M.M. Majidib and M. Pirboveiryc: Response of different species of Brassica to water deficit. Int. J. Plant Prod.,11, 1-16 (2017).

Ray, K., A.K. Pal, H. Banerjee and A. Phonglosa: Correlation and path analysis studies for growth and yield contributing traits in Indian mustard (Brassica juncea L.). Int. J. Bio-resource Stress Manag., 5, 200-206 (2014).

Rivero, R.M., T.C. Mestre, R.O. Mittler, F. Rubio, F.R. Sanchez and V. Martinez: The combined effect of salinity and heat reveals a specific physiological, biochemical and molecular response in tomato plants. Plant Cell Environ., 37, 1059-1073 (2014).

Rosielle, A.A. and J. Hamblin:Theoretical aspects of selection for yield in stress and non-stress environment. Crop Sci., 21, 943-946 (1981)

Salisbury, P.: Potential utilization of wild crucifer germplasm in oilseed Brassica breeding. Proc. ARAB 7th Workshop, Toowoombu, Queensland, Australia, pp. 51-53 (1989).

Sandhu, S.K., M.S. Kang, M.W. Akash and P. Singh: Selection indices for improving selection efficiency in Indian mustard. J. Crop Imp., 33, 25-41 (2019)

Sandhu, S.K., L. Pal, J. Kaur and D. Bhatia: Genome wide association studies for yield and its component traits under terminal heat stress in Indian mustard (Brassica juncea L.). Euph., 215, 188-203 (2019).

Sandhu, S.K., P. Singh, J. Kaur, M. Singh and K. Kaur: Selection indices for enhanced selection efficiency in Indian mustard under terminal heat stress conditions. Indian J. Gen., 80, 103-106 (2020).

Shiranirad, A.H. and A. Abbasian: Evaluation of drought tolerance in winter rapeseed cultivars based on tolerance and sensitivity indices. Žemdirbyste (Ag.), 98, 41-48 (2011).

Sinaki, J.M., E.M. Heravan, A.H. Shirani, G. Noor Mohammadi and G. Zarei: The effects of water deficit during growth stage of canola (Brassica napus L.). American-Eurasin J. Ag. Env. Sci., 2, 417-422 (2007).

Singh, S.P. and A.K. Choudhary: Selection criteria for drought tolerance in Indian mustard (Brassica junceaL.). Indian J. Gen. Plant Breed., 63, 263-264 (2003).

Singh, V.V., G. Pankaj, H.S. Meena and M.L. Meena: Drought stress response of Indian mustard (Brassica juncea L.) genotypes. Int. J. Curr. Mic. Appl. Sci., 7, 2519-2526 (2018). 
Shukla, S., A. Bhargava, A. Chatterjee and S.P. Singh: Estimates of genetic parameters to determine variability for foliage yield and its different quantitative and qualitative traits in vegetable amaranth (A. tricolor). J. Genet. Breed., 58, 169-176 (2004).

Trenberth, K.E., A. Dai, G. Van der Schrier, J. Jones, K.R. Barichivich and J. Briffa-Sheffield: Global warming and changes in drought. Nat. Climate Change, 4, 17-22 (2014).

Vaishnava, A., J.N. Sachan and S.K. Tewari: Genetic divergence for Important quantitative traits in Indian mustard (Brassicajuncea (L.) Czern and Coss). Agri. Sci. Digest, 26, 269-272 (2006).

Vinu, V., N. Singh, S. Vasudev, D.K. Yadava, S. Kumar, S. Naresh, S.R. Bhat and K.V. Prabhu: Assessment of genetic diversity in Brassica juncea (Brassicaceae) genotypes using phenotypic differences and SSR markers. Int. J. Trop. Bio.,61, 1919-1934 (2013).

Warwick, S.I., A. Francis and J. La Fleche: Guide to wild germplasm of
Brassica and allied crops (tribe Brassiceae, Brassicaceae). AAFCECORC Contribution No., 40 (2000).

Winter, S.R., J.T. Musick and K.B. Porter: Evaluation of screening techniques for breeding drought resistance winter wheat. Crop Sci., 28, 512-516 (1988).

Woods, D.L., J.J. Capcara and P.K. Downey: The potential of mustard (Brassica juncea (L.) as an edible oil crop on the Canadian Prairies. Can. J. Plant Sci., 71, 195-198 (1991).

Zhang, W., X. Zou, F. Li and T. Nishio: Computer inference of network of ecological interactions from sampling data. Environ. Monit. Assess., 124, 253 (2007).

Zhang, X., G. Lu, W. Long, X. Zou, F. Li and T. Nishio: Recent progress in drought and salt tolerance studies in Brassica crops. Breed. Sci., 64, 60-73 (2014) 